\title{
Epanalepsis. Sobre The Triumph of Love de Geoffrey Hill
}

\author{
Mario MURGIA ELIZALDE \\ Universidad Nacional Autónoma de México
}

Se ha dicho que Geoffrey Hill es el poeta inglés más importante de su generación y uno de los más influyentes de la segunda mitad del siglo XX y lo que va del XXI. No obstante, su obra es casi desconocida en el mundo de habla hispana y, particularmente, en Latinoamérica, a diferencia de lo que sucede con contemporáneos y compatriotas suyos como Ted Hughes, por ejemplo. En este ensayo se propone una lectura, desde México, de uno de sus poemas largos más recientes, The Triumph of Love, desde la perspectiva de una figura retórica que el mismo Hill ofrece como eje de su desarrollo: la epanalepsis. Se sostiene aquí que la epanalepsis trasciende su definición básica ("el uso de la misma palabra al principio y al final de un verso") para convertirse en una figura extendida de pensamiento que implica un "eterno retorno" a la visión totalizadora de la poesía y a sus posibilidades como medio de análisis de un mundo caótico y esencialmente privado de empatía.

PALABRAS CLAVE: poesía, retórica, epanalepsis, amor, trascendencia.

It has been stated that Geoffrey Hill is one of the most important English poets of his generation and one of the most influential in the late $20^{\text {th }}$ and the early $21^{\text {st }}$ centuries. Nevertheless, the echoes of his poetry have failed to reach the Spanish-speaking world - and particularly Latin America - unlike those of his fellow-countryman Ted Hughes, for instance. This essay is aimed at offering a reading, from Mexico, of one of his latest long poems, The Triumph of Love. This will be attempted by means of the exploration of a particular rhetorical figure that Hill proposes as the very axis of his poem - epanalepsis. It is stated here that epanalepsis transcends its most basic definition - as the repetition of the initial word of a verse at the end - in order to become an extended figure of thought implying an "eternal return" to the all-encompassing vision of poetry. The possibilities of Hill's verse as a means to analyze a chaotic and essentially self-absorbed world are also considered.

KEY WORDS: poetry, rhetoric, epanalepsis, love, transcendence.

For the effect of genius is not to persuade the audience but rather to transport them out of themselves. Invariably what inspires wonder, with its power of amazing us, always prevails over 
what is merely convincing and pleasing. For our persuasions are usually under our own control, while these things exercise an irresistible power and mastery, and get the better of every listener.

Aristotle, Poetics

La poesía, según afirma W. H. Auden, no hace que suceda nada. Continúa diciendo que ésta sobrevive en el valle de su facundia, impasible ante las actividades de ejecutivos, de corredores de bolsa, de sus lectores mismos. Y, no obstante, florece, de maneras casi imposibles, en sus propias palabras, en su boca única y en su inusitada — aunque tal vez del todo omnipresente- expresión. ${ }^{1}$ La postura de Auden ante lo que podríamos llamar "irrelevancia secular" de la poesía es en gran medida una afectación que corresponde a la dicción ceremoniosa y formal propia de un poema dedicado a la memoria del gran poeta muerto, W. B. Yeats, de cuya estulticia en vida Auden participa, y de cuyas dotes poéticas y retóricas se distancia quizá por medio de la visión crítica, casi ajena, del mundo cotidiano, abigarradamente hiperreal, de su propio siglo, el siglo XX. Y sin embargo, la incontenida e incontenible voz de Yeats es también la voz de Auden $y$, por extensión, de todo poeta secular, de aquellas voces que hicieron suyo el pasado siglo y quizá lo que va del presente, aprisionándolos en sus poemas y, al mismo tiempo, llevándolos al terreno de las ocurrencias mundanas pero trascendentes, aunque en sí mismos los poemas no provoquen absolutamente nada.

Geoffrey Hill es uno de tales poetas. Si bien separado de la alcaldada esotérica de Yeats y del verso momentáneamente relevante de Auden, Hill se levanta como una suerte de continuador no asumido de la metafísica moderna del primero y de las meditaciones cotidianas del segundo en una poesía parsimoniosa, grandilocuente hasta rayar en lo sentencioso, oscura y a veces incluso osada en sus vuelos intelectuales. Es, en varios sentidos, el Blake contemporáneo que merece de la crítica y del público tanto explosiones de admiración incondicional, como confusas peroratas que son resultado de lecturas igualmente nubladas por la espesa retórica y la erudición de Hill.

Los poetas abrumadores con frecuencia se hacen de los favores de críticos igualmente intimidantes. Las dogmáticas definiciones de Harold Bloom ${ }^{2}$ señalan, en el caso de Hill, una grandeza poética que lo identifica con una densidad y un poder de alusión imposibles de encontrar (en parte por negación y reticencia, en parte quizá por cierta incapacidad o desencanto retóricos) en la obra de poetas contemporáneos suyos como Kingsley Amis, Charles Thomlinson o Thom Gunn, con la posible excepción de Ted Hughes. Y es que, a diferencia de otros importantes poetas ingleses del siglo $\mathrm{XX}$, Hill es un vate que asume sus capacidades como tal; además, al adoptar una evidente tendencia retórica totalizadora, se impone a la naturaleza parcial, fragmentada y fragmentaria, de la mayor parte de la poesía británica del siglo XX para ofrecer en sus

\footnotetext{
${ }^{1}$ Ver "In Memory of W. B. Yeats".

${ }^{2}$ En distintas ocasiones y en varios textos críticos, Bloom ha llamado a Hill "el mejor poeta británico vivo de su generación y de la segunda mitad del siglo XX".
} 
versos una visión del mundo que parte de su propia conciencia de autosacrificio poético ("I have been touched with that fire, / And have fronted the she-wolf's lair. / Lo, she lies gentle and innocent of desire / Who was my constant myth and terror", clama en "Holy Thursday") para internarse en una suerte de hagiografía de lo cotidiano, con las implicaciones mitopoéticas que esto presupone.

Para abundar en este movimiento característico de la poesía de Hill, parece pertinente volver por un momento a Bloom, quien es de cierto uno de sus más expresos admiradores en el mundo de la crítica. Su apreciación de la poesía de Hill tiene que ver no sólo con una respuesta personal a sus versos, sino también con una postura ante la figura del poeta y el lugar que éste ocupa o al menos debería ocupar en la vida contemporánea:

[...] Hill is a martyrologist. His subject is human pain, the suffering of those who both do and sustain violence, and more exactly the daemonic relationship between cultural tradition and human pain. Confronted by Hill's best poems, a reader is at first tempted to turn away, for the intellectual difficulty of the rugged, compressed verse is more than matched by the emotional painfulness and directness of Hill's vision. Hill does not comfort nor console, and offers no dialectic of gain through loss. His subject, like his style, is difficulty: the difficulty of apprehending and accepting moral guilt, and the difficulty of being a poet when the burden of history, including poetic history, makes any prophetic stance inauthentic (1975: 5).

Con un asombro que recuerda las opiniones del igualmente dogmático Samuel Johnson ${ }^{3}$ sobre el Paraíso perdido de John Milton, Bloom coloca a Hill en una encrucijada y lo enviste de una responsabilidad que se antoja insoportable, la de cargar en sus versos con un carácter profético de indiscutible rareza para el espíritu de lo que, en nuestro propio ámbito, se considera "lo contemporáneo". La encrucijada es aquella que forman la poesía y la historia, una contenedora de la otra en ciertos puntos, en ciertos poetas y en ciertos poemas. Para Bloom y para muchos de sus contemporáneos, la poesía de Geoffrey Hill ha sido marco de esa encrucijada histórico-poética dadas sus obsesiones con la lengua inglesa, con la historia inglesa y, sobre todo, con el devenir de una época que, para Hill, no está en paz ni consigo misma ni con aquellas que la preceden. He ahí el dilema "hilliano", el cómo ajustar la incertidumbre histórica con la certeza de una poética estable en su erudición, aunque desestabilizadora para el lector en sus alcances.

El problema con Hill, en este sentido, es asumir que su poesía se desarrolla, aunque parezca redundante, con el uso de un lenguaje altamente poético y, por lo tanto, complejo y hasta inaccesible en sus atisbos al mundo, a la moralidad y a la lengua que lo representa. Una de las muestras más fehacientes de esto es su largo poema The

\footnotetext{
${ }^{3}$ Hay que recordar que si en la tradición literaria inglesa hubo alguna vez alguien preocupado por la significación del poeta en la vida cotidiana, ése fue el doctor Johnson, como así lo pone de manifiesto su obra monumental The Lives of the Poets.
} 
Triumph of Love ${ }^{4}$ heredero de Blake en su visión casi adivinatoria de la divinidad; de Eliot en su naturaleza de proyecto pictórico-retórico de lo secular, y de Lawrence en su incredulidad para con la moralidad artificiosa de su tiempo. Reza la décima estrofa del poema:

Last things first; the slow haul to forgive them:

Chamberlain's compliant vanity, his pawn ticket saved

from the antepenultimate ultimatum; their strict

pudency, but not to national honour; callous

discretion; their inwardness with things of the world;

their hearing as a profound music

the hollow lion-roar of the slammed vaults;

the decent burials at the eleventh hour:

their Authorized Version - it has seen better days-

'nation shall not lift up sword against nation'

or 'nation shall rise up against nation' (a later

much-revised draft of the treaty).

La tercera persona de estos versos, que juega a un constante ir y venir con la primera a lo largo de las ciento cuarenta y nueve partes que constituyen todo el poema, separa a Hill de una secularidad casi prosaica en momentos clave, cuando ellos (los impersonales "they") se vuelven responsables de las violentas "cosas del mundo", en medio de una ominosa belicosidad condenada a la repetición infinita. Son los últimos versos de la misma estrofa los que tal vez definan el desarrollo del complicado pensamiento poético de Hill en este caso: "In either case / a telling figure out of rhetoric / epanalepsis, the same word first and last". Y es aquí que Hill define la historia y el curso de su propio poema: el poema entero, al menos en el sentido metafórico, emula las estructuras básicas de sus "estrofas" (o "secciones" a falta de un término que nos acerque más a las irregulares y en mucho caprichosas partes que constituyen The Triumph of Love). Hill ha definido ya la epanalepsis: "la misma palabra al principio y al final", y, sin embargo, la epanalepsis en el poema va más allá de la circularidad sintáctica en un grupo de versos. En la poesía de Hill, la epanalepsis se acerca más a su antiguo significado griego, al sentido de "retomar" o, en inglés, a un "taking up again" (Preminger, 1993: 172) que

\footnotetext{
${ }^{4}$ Hay varias obras previas a la de Hill con este título. H. B. Hoffman publicó en 1923 una "Epopeya del gran Noroeste" llamada The Triumph of Love. En 1902, Edmond Holmes publicó una colección de sonetos con el mismo nombre. Sin embargo, quizá la fuente más factible de Hill sea Triomphe de l'amour de Pierre Carlin de Chamblain de Marivaux, obra teatral escenificada por primera vez en 1732. Según el mismo Marivaux, el propósito fundamental de su arte es hacer a los hombres "plus sages et plus humains". Según el escritor Andrew Zawacki, "What may link Marivaux to Hill's seventh and latest individual collection is first the question: Where am I? Like Marivaux's love-baffled protagonists, Hill asks himself this question throughout The Triumph of Love in order to locate himself among the sprawl of its 150 cantos. More important is the spirit of indignation that Hill shares not only with Marivaux, but also with other masters informing this long poem, which Hill describes as Laus et vituperatio, or praise and opposition" (1999).
} 
funciona no sólo como énfasis, sino como unidad estructural en The Triumph of Love. No obstante, la epanalepsis de Hill es sutil, casi invisible, a no ser que el lector intuya y detecte, en medio de referencias casi crípticas, la intención cíclica del poeta, la cual se impone no sólo a través de la palabra, sino también de la ausencia de ésta, en una elipsis que nos obliga a considerar principios y finales a través de silencios y omisiones. El poema mismo nos avisa: "Some qualities are best left unrecognized. / Needless to say, unrecognized is not unacknowledged. Unnamed is not nameless".

El efecto de estos silencios y de esta estructura cíclica del poema tiene ecos sin duda en una suerte de elocuencia muda, si se permite el oxímoron, que representa un comentario tanto sobre la lengua misma, como sobre sus posibilidades en el recuento de la historia, del mundo y de sus expresiones poéticas:

Even now, I tell myself, there is a language

to which I might speak and which

would rightly hear me;

responding with eloquence; in its turn,

negotiating sense without insult

given or injury taken.

Familiar to those who already know it

elsewhere as justice,

it is met also in the form of silence.

(XXXV)

Al equiparar la lengua con la justicia y con el silencio, Hill hace de su propia práctica poética un medio para alcanzar una intensidad lírica que se hace patente no sólo con el uso frecuente y habilidoso de recursos retóricos, sino con un constante ejercicio de la erudición, el cual supera la tentación de convertirse en oscuridad vacía para dar pie, por el contrario, a una exploración de lo sublime a través de las capacidades evocativas de la lengua. En este sentido, los vuelos poéticos de Hill son casi neoplatónicos. En The Triumph of Love el poeta se acerca a una suerte de apología de lo sublime a través de versos que, a pesar de su carga intelectual, poseen ante todo una accesibilidad sensorial cuya importancia en la poesía fue descrita ya por Longino hace al menos veinte siglos:

Much in the same way that dimmer lights vanish in the surrounding radiance of the sun, so an all-embracing atmosphere of grandeur obscures the rhetorical devices. We see something of the same kind in painting. Though the highlights and shadows lie side by side in the same plane, yet the highlights spring to the eye and seem not only to stand out but to be actually much nearer. So it is in writing. What is sublime and moving lies nearer to our hearts, and thus, partly to a natural affinity, partly from brilliance of effect, it always strikes the eye long before the figures, thus throwing their art into the shade and keeping it hid as it were under a bushel (1999: 233). 
Y así, lo que nos deslumbra de la cuarta estrofa de The Triumph of Love, por ejemplo, es, además de su fuerza visual (la cual prevalece durante gran parte del poema ocasionando asociaciones semánticas casi inusitadas al combinarse con evocaciones más afines a esferas metafísicas de intelectualidad), la superposición de planos metafóricos, en la que, por ejemplo, las plantas, como objetos "palpables" a través de la vista y representaciones de un mundo externo, se ven subordinadas a las imágenes proyectadas sobre el cristal de la ventana que las separa de quien las observa, quedando al final incólumes, inmodificadas a pesar del efecto de la luz:

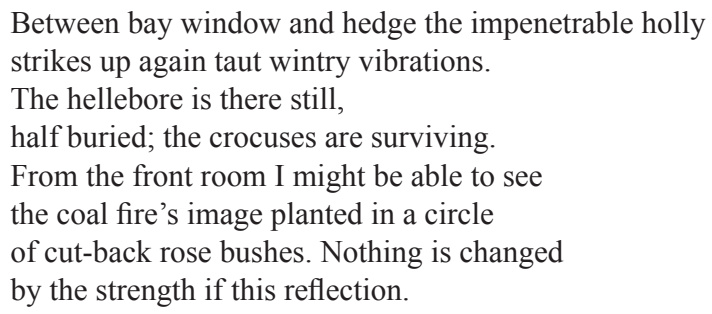

Hill parece pensar en Longino al componer su estrofa: las impresiones miméticamente visuales dan paso, en los últimos dos versos, a una impresión estática que supera los terrenos sensoriales de la imagen para adentrarse en algo que podría llamarse "lo emotivo de la stasis", una sensación de inmovilidad ominosa, profundamente desconsoladora, que fuerza al lector a una respuesta de empatía con el poeta, creando así el efecto de lo sublime que deja atrás al ojo para llegar al corazón. Los recursos retóricos han sido superados, casi desde el principio del poema, y la epanalepsis ha dejado de ser un componente estructural para convertirse en instancia de lo sublime en The Triumph of Love.

De esta manera, la epanalepsis de la que echa mano Hill en su poema recrea un movimiento eterno que, sin embargo y debido a su circularidad, da la impresión de estancarse en elucubraciones sobre las consecuencias del pasado y, por lo tanto, de la idea de tradición que lo precede. Según Henry Hart, uno de los críticos más puntuales de Hill,

For Hill, tradition is a "trust", those who guard it trustees, and those who benefit from it beneficiaries. It is also a trust in the sense that it is a big business, a "combine" of firms, a monopoly, whose managers fix the prices by dictating which subjects will and will not be taught. A "combine" can also be a wheat thresher (Hill compared the dead to winnowers in "God's Little Mountain"), but, on a more mundane level, it is a group of devotees competing to "profit" from the past. As "doves" and "witnesses", they parody holy spirits and martyrs as much as they emulate them. At the poem's end, the plant dug from the hotbed of cultivated soil (the ground of tradition) offers a radical, and perhaps necessary, alternative to the culture-bound poet (1986: 31-32). 
Y el beneficio que obtiene Hill de la tradición es innegable. El peso de la tradición (de Milton a Rilke, de Donne a Leopardi) le proporciona una visión poética que, a partir de lo inmediato, construye una suerte de monopolio retórico que le permite, desde una posición privilegiada, administrar sus propios recursos, así como apropiarse de lo que para él es una inevitable (aunque no siempre feliz) herencia cultural. En el poema al que Hart hace referencia, "God's Little Mountain", Hill sostiene: "Now I lack grace to tell what I have seen; / For though the head frames words the tongue has none". No obstante, el silencio del cual Hill se hace víctima en este poema escrito en la década de los cincuentas del siglo pasado se compensa con una elocuencia, quizá no lingüística, sino del todo sensitiva y erudita en The Triumph of Love, donde, curiosamente, quien vence no es el amor mismo, sino una terrible sensación de vacío y dolor abigarrado, los cuales se identifican, como lo había señalado Bloom, con una necesidad de autoinmolación para beneficio del poema y de la construcción de todo un mundo poético que sea, a la vez, uno mismo con el mundo de la desesperada realidad circundante:

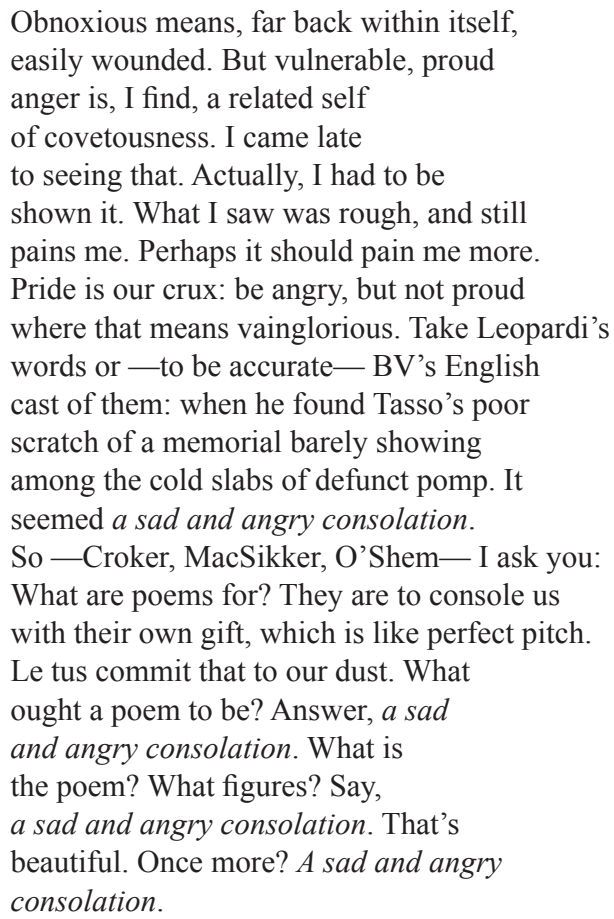

¿Y dónde está para Hill la belleza en ese triste y furioso consuelo, a fin de cuentas? Quizá se encuentre precisamente en la certeza del poema como fuente de sapiencia, de inmediatez e incluso de terror. Es sólo cuando el poema se satisface a sí mismo más allá de la retórica que Hill encuentra redención y permanencia en una tradición que, como The Triumph of Love mismo, es indudablemente circular. La epanalepsis ha dejado de 
ser así una mera figura retórica para convertirse, por medio de la erudición, en toda una figura de pensamiento: una continua metonimia de la tradición poética a la que Hill a la vez pertenece y se sacrifica en lo sublime de sus propios versos.

\section{Obras citadas}

Aristotle. Poetics. 1999. Trad. Stephen Halliwell. Cambridge, Mass.: Harvard University Press. (Loeb Classical Library)

BASAVE y FernáNDEZ DEL VAlle, Agustín. 2002. ¿Qué es la poesía? Introducción filosófica a la poética. México: FCE. (Lengua y Estudios Literarios)

BERISTÁIn, Helena. 1992. Diccionario de retórica y poética. México: Porrúa.

HART, Henry. 1986. The Poetry of Geoffrey Hill. Carbondale, IL.: Southern Illinois University Press.

HiLlL, Geoffrey. 2000. New and Collected Poems, 1952-1992. Nueva York: Houghton Mifflin. 1998. The Triumph of Love. Nueva York: Houghton Mifflin. 1975. Somewhere is Such a Kingdom. Nueva York: Houghton Mifflin.

Longinus. On the Sublime. 1999. Trad. W. H. FyFE. Cambridge, Mass.: Harvard University Press. (Loeb Classical Library)

Preminger, Alex. 1993. The Princeton Encyclopedia of Poetry and Poetics. Princeton: Princeton University Press.

ZaWACKI, Andrew. 1999. "The triumph of Love". Boston Review. A Political and Literary Forum. http://bostonreview.net/BR24.1/zawacki.html 